\title{
防火的視点からみた各種樹葉の含水率に関する研究
}

\section{Study on Water Content Ratio of Tree Leaves from Point of View of Fire Prevention Effect}

\author{
岩崎 哲也* \\ Tetsuya IWASAKI
}

\begin{abstract}
There were some differences in the results of existing measurements on water content ratio of leaves. Therefore, the ratios of water content in 55 species of leaves were measured under the same conditions when leaf samples were taken. The result of measurement showed that there are differences in the water content between species and leaves. Next, seasonal changes in water content of leaves from 29 evergreen species were compared during summer and winter. As the result this comparison, it was found that the water content of leaves in Tokyo area is highest in summer. In addition to this, results of measurements assessing annual changes in water content of leaves from 6 broadleaf tree species indicated that the water content ratio in evergreen broad-leaved trees was at a minimum before coming into leaf during the winter and spring seasons. After showing the highest ratio of the season just after leaf flush, the ratio began gradually decreasing until the winter season. For deciduous broad-leaved trees, their ratio of water content has a tendency to be highest in April and drops temporarily in midsummer. Moreover, the results in this research and the results of existing measurements were integrated, the water content ratios of 178 species of trees were arranged and the tendency was grasped.
\end{abstract}

Keywords: water content ratio, fire prevention, seasonal change, heat, prevention of disaster キーワード : 含水率, 防火, 季節変動, 熱, 防災

\section{1.はじめに}

木材の燃焼特性を考える際, その燃焼速度は含水率の $1 / 3$ 乗 に逆比例するなどの研究例 ${ }^{11}$ があり, 樹木の防火力についてあ水 分によるところが大きいと考えられる。こうした着眼点から，樹 葉の含水率について測定した既往研究は幾つかあるが，代表的な 研究例をみても計測值に大小のばらつきがあり, その原因の検証 や各研究結果の一元的な整理を行う必要性があると考える。

また, わが国は四季の変化に富み, 気温や日照, 湿度等の変動 があるため, 樹木の生理活性にも季節変動がある。例えば, 落葉 樹に認められるように, 生活・形態に大きな变化を示す樹木が存 在する。同様に, 常緑樹の葉にも何らかの変動があることが予想 される。含水率の季節変動と防火力について詳しく論じた研究例 はないが，下記の 2 文献に記述されている内容が興味深い。すな わち, 木村・加藤 $\left.{ }^{2}\right)$ は, 『新葉展開前後をのぞき, 樹葉含水率の 年間格差は認めない。』としいる一方, 火災便覧 ${ }^{3)}$ では常緑針 葉樹の樹葉水分は年間变化を有すむのとしている。

そこで本研究では, 既往研究の結果について整理を行うととも に, 樹葉採取時の条件 (季節, 地域, 時刻, 部位等) をできる限 り均一化して含水率を計測し, 樹種間や季節による含水率の違い について考察する。

\section{2. 樹葉の含水率の測定差および年間変動について}

\section{（1）既往研究における測定値の相違}

既往研究では, 実験計測の回数や測定条件などの記録の詳細さ から以下の 3 つの研究が信頼できると考える。すなわち中村 ${ }^{4)}$ は, 133 種類の樹木の葉について含水率を計測し, その脱水時間の長 短によって樹種別の防火力を類型化している。また木村・加藤 ${ }^{2}$ は, 75 種の樹葉について含水率を測定し, 樹葉は平均して 60〜 $70 \%$ 含水率を持ち, 落葉広葉樹がもっとも多量, ついで常緑広 葉樹であって, 針葉樹は比較的少ないとしている。また, 新葉は 古葉より含水率が高く, 新葉展開前後をのぞき年間格差は認めな
いとしている。また岩河 ${ }^{5)}$ は 31 種の樹葉について測定し, マテ バシイPasania edulis44.9\%〜イチョウGinkgo biloba81.3\%の 範囲であったとしている。

これらの測定結果について，3者すべての研究で扱われた樹種 は 11 種あり, 各々の最大差は表一 1 に示すと㧍りである。この 表によると, 測定值の差は最大 $11.8 \%$ である。岩河の測定値が 高めに, 中村の測定值が低めにある傾向があるが, この 3 者の研 究例は, $100 \sim 105^{\circ} \mathrm{C}$ 電熱器を用い乾燥の方法はほぼ同じである から, その他の条件, 例えば樹葉を採取した位置や季節, 個体差, 地域差などによって異なる可能性がある。そこで本研究では, 樹 葉を採取する際の条件を設定して含水率を計測することとしたい。

\section{(2) 樹葉の含水率の測定}

(i ) 樹葉採取時の条件設定および樹種

採取時の条件について，木村・加藤 ${ }^{2}$ によると，1）南向きの 葉について，2）生育良好で，3）正形葉を用いたとある。条件 1) は, 生育良好な葉を選ぶためと思われるが, 南向きの位置で は直射日光による温度や光量の日あるいは年間較差が大きいと考 えられ，それにともなう生理活動の強弱による影響が少なくない と考える。2）と３）の条件は若干主観的である。そこで, 本研 究では以下の採取条件を定めることとした。このうち条件イ）に ついては, 試料を採取した公園緑地等では低い位置の葉に泥砂の

\begin{tabular}{|c|c|c|}
\hline 樹 種 & $\begin{array}{l}\text { 含水率の } \\
\text { 差 }(\%) \\
\end{array}$ & $\begin{array}{l}\text { 研究者 }(\text { (村·加藤 } 2 \text { 、中 } \\
\left.\text { 村 }{ }^{4)} \text { 、岩河 }{ }^{5}\right)\end{array}$ \\
\hline トンゴジュ Viburnum awabuki & 0.5 & 木村一中村 \\
\hline ヤキ Zelkova serrata & 1.6 & 中村一木村および岩河 \\
\hline バキ Camellia japonica spp. & 5.1 & 木村・加藤一岩河 \\
\hline サキ Euonymus japonicus & 5.4 & 村 ·加藤一中村 \\
\hline オキ Aucuba japonica & 6.0 & 岩河一中村 \\
\hline イダジイ Castanopsis cuspidata var. sieboldii & 8.5 & 木村 $\cdot$ 加藤一中村 \\
\hline ザンカ Camellia sasanqua & 9.1 & 岩河一中村 \\
\hline Гテバシイ Pasania edulis & 9.6 & 木村一岩河 \\
\hline スノキ Cinnamomum camphora & 10.2 & 岩河一木村·加藤 \\
\hline チョウ Ginkgo biloba & 11.2 & 岩河一中村 \\
\hline ベラ Pittosporum tobira & 11.8 & 岩河一中村 \\
\hline
\end{tabular}

\footnotetext{
*(財)練馬区都市整備公社
} 
付着量が多いことと, 他の採取条件を視認しやすいことから, 概 ね $1.5 \mathrm{~m}$ の位置を基本としたあのである。

ア）北向きの枝の葉

イ）高さ $1.5 \mathrm{~m}$ 程度に位置する葉

ウ）虫害の影響のない葉

エ）病徴の現れていない葉

オ）周辺の葉と比較し，十分に成熟した葉色を示していること

カ） 3 日以内に降雨のないこと

キ) 朝 $9: 00$ 前後に採取すること

ク）夏季（ 6 月〜 9 月）に採取すること

採取した樹種は, 常緑広葉樹 26 種, 落葉広葉樹 23 種, 針葉樹 3 種, 夕ケ・ササ類 3 種の計 55 種で, 公園や庭など屋外居住空 間において一般的に植栽されているあのである。

また, 樹葉の採取は 2001 年扔よび 2002 年に行った。採取場所 は，東京都港区など主として東京都区部城南地域である。

(ii) 測定機器および測定条件等

樹葉の乾燥には, 電熱器により炉内の温度を一定に保つことが できる電気式恒温炉 (島津製作所製ベストアクメ恒温乾燥炉) を 用い, 質量の計測には $1 / 100 \mathrm{~g}$ の表示性能を持つ精密天秤（島 津製作所製 EB330S）を使用した。樹葉は，同一個体から各樹種 につき 6 枚ずつ採取し， 3 時間以内に生質量を計測したのち，10 $5{ }^{\circ} \mathrm{C}$ にいて質量減少が確認できなくなるまで炉乾を行った。

\section{(iii）測定結果}

測定の結果, 55 種の樹葉の含水率はキンモクセイOsmanthus fragrans var. aurantiacus48.8\%からアジサイ Hydrangea macrophylla82.8\%の範囲であり, 生活・形態別 ${ }^{6)}$ には表 -2 に 記す範囲抢よび平均值である。これらの傾向を整理すると下記の 3 項であり, 前述した木村 ・加藤, 岩河の測定結果と概ね一致する。

(1) 落葉広葉樹の含水率が比較的高い。

(2) 針葉樹と夕ケ・ササ類は低い。

(3) 常緑広葉樹は上記の中間である。

また今回の測定では，各樹種につき 6 枚の樹葉を測定しており， 表一 1 と同樹種について, 樹葉ごとの最大差を表一 3 に整理する。

先に, 先行する 3 研究の測定值に差があることを示し, その要 因を採取条件等によるものと仮定して今回の測定を行ったが，表一 1 と表一 3 の測定結果をみると, 先行 3 研究の測定において差が 大きい樹種は，筆者の測定でも葉ごとの差が大きい傾向がある。 今回の筆者の計測では, ある程度採取時の条件を限定したが, そ れであクスノキで $8.59 \%$ あ差があり, 先の 3 研究による差之 比較して明らかに筆者の測定に打ける差が小さいとは言い難い。 したがって, 地域差や季節差など他の条件による差あるいは, 樹

表 -2 生活・形態別樹葉の含水率（55 種）

\begin{tabular}{|c|c|c|}
\hline 生活 - 形態 & $\begin{array}{l}\text { 測定値の範囲 } \\
(\%)\end{array}$ & 平均值（\%) \\
\hline $\begin{array}{l}\text { 常緑広葉樹 (26 種) } \\
\text { 落葉広葉樹 (23 種) } \\
\text { 針葉樹 (3 } 3 \text { 種) } \\
\text { タケ・サ少 }\end{array}$ & $\begin{array}{l}48.8 \sim 74.1 \\
53.6 \sim 82.8 \\
53.5 \sim 65.1 \\
54.8 \sim 64.7\end{array}$ & $\begin{array}{l}62.6 \\
66.6 \\
60.1 \\
60.8\end{array}$ \\
\hline
\end{tabular}

\section{表 $-3 \quad 6$ 枚の樹葉含水率の最大差}

\begin{tabular}{|c|c|}
\hline 樹 種 & 含水率の差 $(\%)$ \\
\hline アオキ Aucuba japonica & 1.86 \\
\hline サンジジュ Viburnum awabuki & 2.01 \\
\hline マテバシイ Pasania edul is & 4.15 \\
\hline ケヤキ Zelkova serrata & 4.20 \\
\hline マサキ Euonymus japonicus & 4.75 \\
\hline ツバキ Camellia japonica spp. & 5.11 \\
\hline サザンカ Camellia sasanqua & 5.16 \\
\hline トベラ Pittosporum tobira & 6.52 \\
\hline イチョウ Ginkgo biloba & 7.22 \\
\hline スダジイ Castanopsis cuspidata var. sieboldii & 7.59 \\
\hline クスノキ Cinnanomum camphora & 8. 59 \\
\hline
\end{tabular}

種によって，葉ごとの含水率にばらつきの大小がある可能性など が考えられる。

\section{（3）季節による含水率の変動について}

1。はじめにに記したように，『樹葉の含水率の年間格差は認 めない。』とする研究がある一方で, 火災便覧ではスギ Cryptomeria japonica，ヒノキChamaecyparis obtusaなど 8 種 の針葉樹の月別值を記載している。それをみると，これらの針葉 樹は 3 月から 5 月に含水率が低下し， 7 月から 8 月に高くなって いる。樹木の防火効果を考える場合, 火災の発生頻度には季節性 がある7゙ことから，こうした含水率の季節変動について明らかに しておく必要がある。

そこで本研究では，同一個体の葉について含水率を月ごとに測 定し，季節による含水率の变動を確認することとする。

（i ）樹葉含水率の年間変動

表一 4 に，常緑広葉樹ならびに落葉広葉樹それぞれ 3 種につい て，月ごとの含水率を測定した結果を示す。葉の採取条件や測定 条件は，前項と同様である。

これによると，落葉樹はいずれも 4 月の含水率が最高となって いて, イチョウとケヤキZelkova serrataは 8 月に, ソメイヨシ ノPrunus yedoensisは 10 月に最低值を示した。4 月に最高值を 示すことは, 目視では十分に展葉したと判断した葉でも, 新葉の 名残を留めているのであろう。また盛夏に一旦低下し，9月に再 び上昇する傾向がある。一方，常緑樹はクスノキCinnamomum camphoraが 4 月，トウネズミモチLigustrum lucidumが 6 月, マテバシイが 5 月と，いずれも春季から初夏に含水率が高い。ま た盛夏の低下は認められず, 最低值はトゥネズミモチとマテバシ イが 4 月, クスノキが 1 月となっている。こうして, 常緑樹は冬 季から春季の葉の展開期前に最低值を示すことと, その後最高値 を示したのち，翌年の冬季に向けて漸減していくことが分かった。 これは，先の火災便覧に記載された常緑針葉樹の季節变動とも同 様な傾向である。このように, 冬季から春季にかけて常緑樹の含 水率が低下する傾向や，冬季の落葉樹の葉がないことは，冬季に 火災発生件数が多いわが国では好ましくない。しかし今回，落葉 樹は展葉直後の含水率が高いことが明らかになったことから，展 葉が早い落葉樹は，冬季に次いで多発する春季の火災7) に効果が ある可能性がある。例えば, 1993 年 4 月, 高知県において発生 した山林火災が落葉樹林によって焼け止まった例 $\left.{ }^{8}\right)$ が報告されて いる。この報告では，『この時期にこれら樹木の防火力は期待で きないため，地形によるあのである。』としているが，展葉期の 高い葉の含水率之，それを助ける幹や枝中の水分や根の活性など, 春季の火災に対する効果について，今後検討すべき課題之考える。 また，表一 4 の標準偏差抢よび図－1 に示すように，樹種毎の

\section{表 -4 樹葉の月別含水率}

\begin{tabular}{|c|c|c|c|c|c|c|}
\hline & \multicolumn{3}{|c|}{ 落葉広葉樹 } & \multicolumn{3}{|c|}{ 常緑広葉樹 } \\
\hline & $\begin{array}{c}\text { イチョウ } \\
\text { Ginkgo } \\
\text { biloba }\end{array}$ & $\begin{array}{l}\text { ケヤキ } \\
\text { Selkova } \\
\text { serrata }\end{array}$ & $\begin{array}{c}\text { ソメイヨシノ } \\
\text { Prumus } \\
\text { yedoensis }\end{array}$ & $\begin{array}{l}\text { クスノキ } \\
\text { Cinnamomum } \\
\text { canphora }\end{array}$ & $\begin{array}{c}\text { トウネズミモチ } \\
\text { Ligustrum } \\
\text { Iucidum }\end{array}$ & $\begin{array}{c}\text { マデバシイ } \\
\text { Pasania } \\
\text { eddlis }\end{array}$ \\
\hline $2001 / 11$ & 73.9 & 60.0 & 60.7 & 61.5 & 67.1 & 52.8 \\
\hline " $\quad 12$ & 落葉 & 落葉 & 落葉 & 60.5 & 67.5 & 52.8 \\
\hline $2002 / 1$ & - & - & - & 53.5 & 65.4 & 52.5 \\
\hline " $\quad 2$ & - & - & - & 54.7 & 63.2 & 50.8 \\
\hline " $\quad 3$ & - & 幼葉 & - & 56.6 & 63.8 & 49.6 \\
\hline " 4 & 76.2 & 73.7 & 69.7 & 65.6 & 61.7 & 47.7 \\
\hline " 5 & 75.7 & 65.2 & 65.8 & 62.0 & 65.9 & 61.3 \\
\hline " 6 & 71.2 & 63.6 & 63.3 & 63.0 & 68.0 & 58.0 \\
\hline " 7 & 73.8 & 60.5 & 60.5 & 64.5 & 66.5 & 56.7 \\
\hline " 8 & 68.7 & 55.8 & 63.4 & 62.0 & 65.9 & 55.8 \\
\hline " 9 & 75.3 & 61.1 & 63.4 & 62.6 & 67.1 & 54.6 \\
\hline " 10 & 75.9 & 58.0 & 59.5 & 61.5 & 66.7 & 54.6 \\
\hline 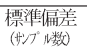 & $3.9(48)$ & $6.2(48)$ & $3.6(48)$ & 5. 1(71) & 2. $2(72)$ & 4. $3(72)$ \\
\hline
\end{tabular}



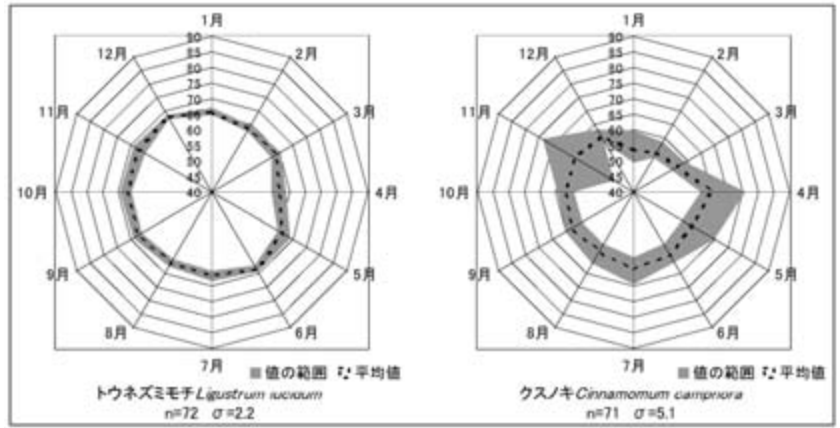

図-1＼cjkstart樹葉含水率の年変化と測定値の範囲（\%)

測定值にばらつきの大小があることが分かった。

(ii）冬季と夏季の樹葉含水率

前項で, 常緑広葉樹の樹葉含水率は, 冬季加春季にかけ最低 となり, その後最大值を示し, 翌年の冬季に向け減少していくこ とを示した。このことから, 常緑広葉樹については, 含水率の変 動が大きい春季を避けて計測すると比較的誤差が少ないと思われ る。そこで本項では, (2) 樹葉の含水率の測定で夏季（6月～ 9 月）の含水率を測定した 55 種の樹葉のうち, 常緑樹 29 種につ いて冬季の含水率を計測し, 前項の常緑広葉樹 3 種で認められた 季節変動の補足確認を行うこととする。なお，冬季の測定は，1 月から 3 月初旬にかけ行った。

図 -2 に, 冬季と夏季の測定結果について, 夏季の含水率が高 い順に整理する。この図から分かるように, 常緑樹 29 種中, 27 種について冬季より夏季の含水率が高い。このことから, 前項の 3 種で認められたように, 春季あるいは初夏から冬季に向け含水 率が減少していく傾向は, 多くの常緑広葉樹に認められる可能性 がある。また, キョウチクトウNerium indicumやマメッゲIlex crenata f. bullata, チャノキThea sinensisなどは夏季の含水率 が高いが冬季との差が大きく, シャリンバイRhaphiolepis umbellate, マダケPhyllostachys bambusoides, サワラ Chamaecyparis pisifera, ビワEriobotrya japonicaなどは冬季 と夏季との差が小さいなど，樹種によって差違のあることが分かっ た。

\section{3. 各種樹葉の含水率}

先述したように，樹木の防火効果に関する既往研究では，中村， 木村・加藤, 岩河の 3 研究の記録が詳しい。これら 3 研究と筆者 の計測は, 加熱器機や加熱強度が概水同等であり, 各研究におけ る測定結果の平均を算出することにより, 樹種を増やすこととデー 夕の精緻化を図ることが, ある程度可能であると考えられる。そ こで, ここでは先行する 3 研究と筆者の測定值を合体して整理し てみたい。

表一 5 は, 各研究の結論值の平均值の高い順に整理したもので あり, 筆者の測定のうち常緑樹については夏季と冬季の平均を結 論値とした。全樹種 178 種の平均は，63.4\%である。

この表から, 樹種による含水率の差は既往研究で認められる通 り著しいこと, モクレン科, ウコギ科, クワ科, ミズキ科, ブド ウ科, アオイ科などの含水率が高く, イネ科, ブナ科, バラ科, ニレ科, モチノキ科, カバノキ科などの含水率が低い傾向がある ことが分かる。

\section{4. まとめ}

樹葉の含水率について, 先行する研究にみられる測定值のばら つきが樹種別評価を行う際の課題の一つであった。本研究では, 樹葉の採取条件をある程度一定にして計測した結果, クスノキ,

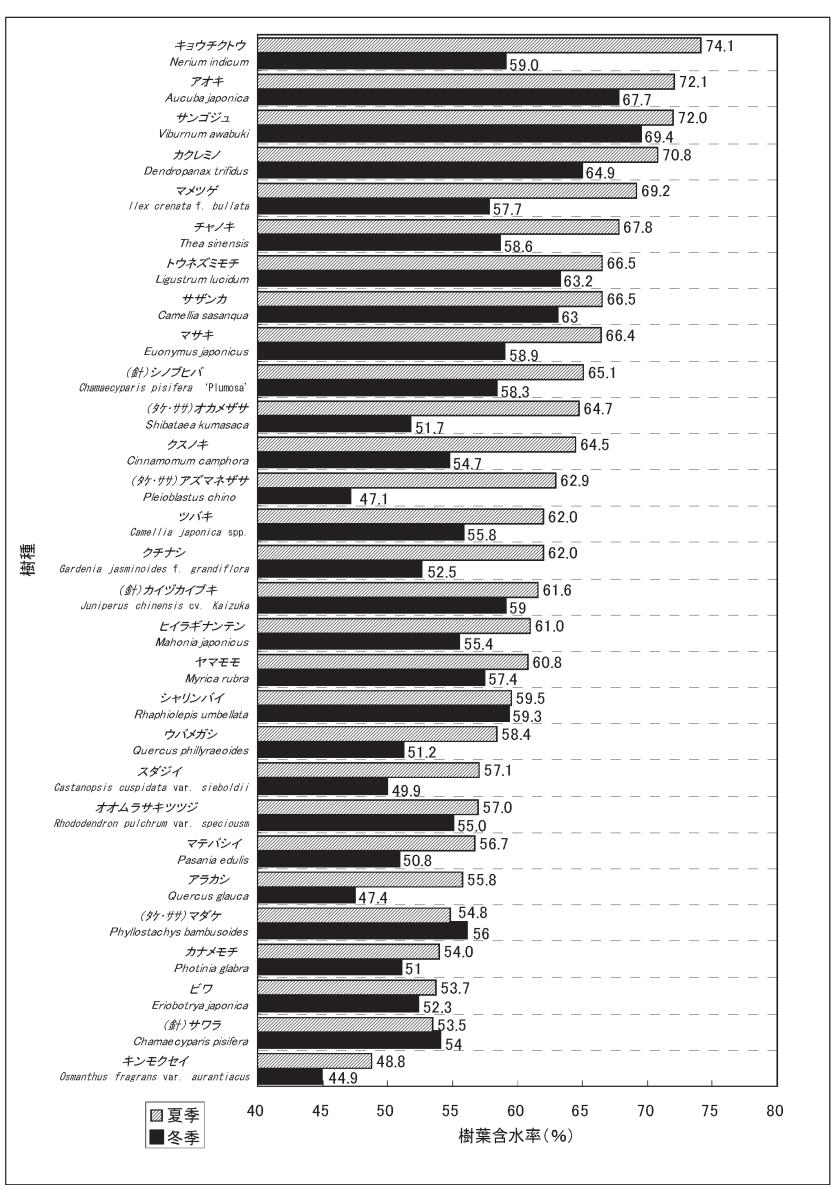

図－２＼cjkstart冬季と夏季の樹葉含水率（2001-2002 東京）

イチョウ，トベラ，スダジイなど樹種によってそれぞれの葉の含 水率にばらつきが生じやすいものがある可能性が示された。これ らの樹種は, 都市環境に適応し, 土㙵の水分条件の变動に比較的 強いなどの性質があると思われるが，樹葉含水率との関係につい て検証が必要である。今後は, こうした樹種の樹種別評価に際し 計測数を増やして精緻化を図るとともに，地域差などの環境条件 によって含水率が変化しやすい樹種があることを前提に樹木の防 火力を考える必要がある。

また， 3 種類の常緑広葉樹の含水率の年間变動を計測したとこ 万, 東京地方では $1 \sim 4$ 月, 特に 2,3 月は含水率が低く, 5 〜 10 月は高いことが分かった。そして，29 種の造園樹木について 冬季と夏季の含水率の差を計測したところ, ほぼすべての樹種に ついて夏季の含水率が冬季上りも高いことが明らかとなった。こ のことから，樹葉の含水率に関しては，季節差があることを考慮 して樹木の防火力に関する研究を進める必要性がある。そしてア ズマネザサPleioblastus chino（夏冬差 15.8\%）やキョウチクト ウ（同差 15.1\%)，オカメザサ Shibataea kumasaca（同差 13.0\%）など含水率の夏冬差が大きい樹種は, 特にこの季節性を 加味して樹種別評価を検討する必要があると思われる。

また今回の測定は，主として東京都港区など，東京都区部城南 地域の樹木を対象としたあのである。そのため, 今後は地域差に ついての検証も必要である。

謝辞

本研究を進めるに当たり, 岩河信文先生 ((株)都市計画研究所),

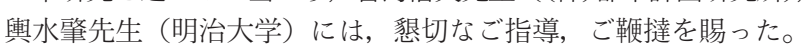
また, 倉本宣先生 (明治大学), 斉藤庸平先生（兵庫県立大学） 
表 -5 各種樹葉の含水率（\%)

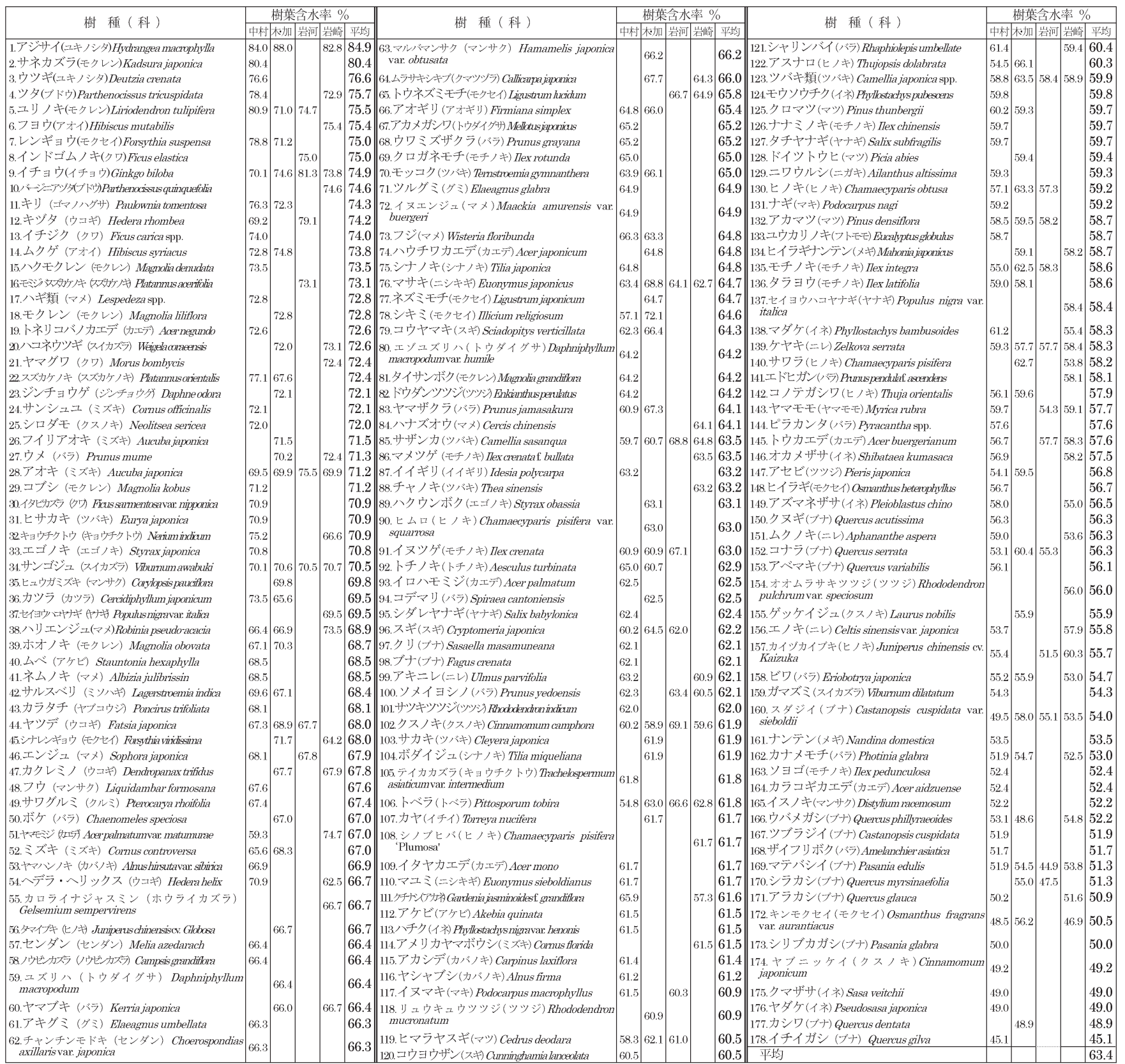

には, 多くの詳しいご助言を賜った。この場を借りて, 厚く御礼 申し上げる。

\section{補注および引用文献}

1) 守屋忠雄（1956）：木材の燃焼について一燃焼速度に及ぼす 含水率の影響：日本火災学会論文集 5(3)，69-72

2 ) 木村英夫 ・加藤和男 (1949)：樹木の防火性に関する研究 : 造園雑誌 11(1), 11-15

3 ) 日本火災学会（1955）：火災便覧：コロナ社, 東京 1 , 549pp.

4 ) 中村貞一 (1948)：樹林防火力の研究一第 1 報 緑地用樹木
の葉の含水率と脱水時間についての比較実験：造園雑誌 12(1), $13-17$

5 ) 岩河信文 (1982)：都市に㧍ける樹木の防火機能に関する研 究: 東京大学博士論文

6 ）ここでは植物の生活形掞よび形態・解剖学的分類（樹葉形状, 形成層の有無）から区分し，生活・形態別とした。

7 ) 消防庁 (2001)：平成 13 年版消防白書：ぎょうせい, 東京, $544 \mathrm{pp}$.

8 ) 松田誠祐 $・$ 大年邦雄・西村武二・日浦啓全・山下雅子・大輪 安信（1995）：1993 年 4 月高知県物部村山林火災に関する調 查研究: 高知大学学術研究報告第 44 巻自然科学, 73-89 